\title{
Internet-telefoni i fjernundervisning
}

Om potentialet $i$ at inddrage computer-medieret mundtlig dialog til at supplere skriftlige netbaserede undervisningsformer

\author{
Jacob Thommesen \\ Ekstern lektor, Ph.D. \\ MCC-uddannelsen \\ Institut for Kommunikation, Journalistik \\ og Datalogi, \\ Roskilde Universitetscenter \\ jthommes@ruc.dk
}

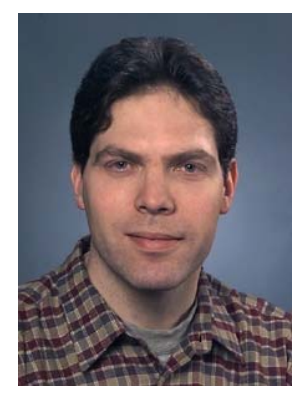

Jacob Thommesen er ekstern lektor på master-uddannelsen i computer-medieret kommunikation på RUC, hvor han bl.a. underviser i computer-støttet videndeling, elektronisk demokrati og digital forvaltning. Han underviser desuden i organisationsteori og virksomhedskommunikation på Handelshøjskolen i København. Jacob Thommesen har skrevet Ph.D.-afhandling om intranet og tvcergående kommunikation i organisationer.

Synkron lyd giver mulighed for at etablere en mundtlig dialog i forbindelse med fjernundervisning, uden at deltagerne skal bruge tid og penge på at nå frem til et fælles undervisningslokale. Den mundtlige dialog er velegnet til hurtigt at afklare misforståelser og diskutere forskellige tolkninger af samme 'indhold', og teknologien kan derfor anbefales i undervisningssammenhænge, hvor der let kan opstå tvetydighed, hvad enten det skyldes et komplekst og tvetydigt indhold i kurset, eller at deltagerne har forskellige baggrunde og forståelsesrammer. For at få et udbytte af et sådant 'virtuelt møde', er det vigtigt at udnytte muligheden for en høj grad af dialog, hvilket kræver forberedelse og motivation af deltagerne.

Jeg vil her uddybe dette argument ved at diskutere erfaringerne fra et konkret eksperiment, hvor dette 'virtuelle møde' supplerer en anden computer-medieret undervisningsform: en netbaseret, skriftlig dialog med udgangspunkt i nogle opgaver og spørgsmål formuleret af underviseren. I den forbindelse vil jeg først gøre rede for tankerne bag, og erfaringer med denne anden undervisningsform, fordi den udgør selve grundlaget for kurset og dermed er en væsentlig baggrund for eksperimentet. Jeg hævder, at den skriftlige diskussion på den ene side skaber nogle bedre forudsætninger for det virtuelle møde, men at der på den anden side i forbindelse med denne skriftlige diskussion også opstår et behov for en mundtlig dialog. Endelig bør jeg gøre opmærksom på, at der ikke er tale om et kontrolleret eksperiment, men om et mere uformelt forsøg på at afprøve denne mulighed.

\section{Skrift og tale via computeren}

\section{Netbaseret dialog: nye perspektiver for en 'gammel' undervisningsform}

På Masteruddannelsen i Computer-mediated Communication (MCC) har vi på flere af kurserne siden sommeren 2003 prøvet at indføre en ny model, hvor deltagerne i højere grad skal føre en skriftlig diskussion over RUC's samarbejdssystem, BSCW, fremfor - som tidligere - at arbejde sammen i grupper om at skrive en opgave. Størstedelen af den 'normale' undervisning foregår på internater på Bornholm, hvor deltagerne mødes tre gange i løbet af semesteret. Et 
kursus forløber typisk mellem to internater, dvs. med indledende forelæsninger mm. på det første internat, hvorefter deltagerne i den mellemliggende periode arbejder videre med stoffet med henblik på en skriftlig aflevering, der danner baggrund for opsamling og evaluering på det efterfølgende internat. Dette gælder således det ene af de to kurser omtalt i denne artikel, mens det andet er et såkaldt tre-ugers kursus, der foregår uafhængigt af internaterne på Bornholm. Men før jeg beskriver den nye 'model' mere detaljeret, vil jeg præsentere nogle af de overordnede ideer bag ønsket om at lægge større vægt på en skriftlig diskussion. Ideerne er baseret på forskellige teorier om computer-medieret kommunikation, som er præsenteret $\mathrm{i}$ Appendiks B.

Intentionen med den skriftligt baserede undervisning er, at deltagerne får bedre tid til refleksion, og til at inddrage de teoretiske tekster løbende, end i forbindelse med en mundtlig dialog ansigt til ansigt. Der er bedre mulighed for at gennemtænke kritiske indlæg, og for at fastholde en diskussion og vende tilbage til tidligere indlæg - som man ellers ville glemme i en tidsbunden mundtlig dialog. Desuden tilbyder skriftliggørelsen en række fordele frem for den mundtlige dialog, såsom bedre muligheder for logisk struktur, analytisk tilgang og abstraktion (Ong 1982). Samtidig er der netop tale om en form for dialog, hvor deltagerne i høj grad kommenterer og diskuterer med hinanden - denne skriftlige dialog er formodentlig en ny kommunikationsform, der først er blevet mulig med computermediet.

Ud over skriftligheden og tidsperspektivet - dvs. at dialogen strækkes over længere tid og fastholdes i mediet - kan der også være en fordel ved medieret kommunikation, at manglen på nonverbale signaler gør det sværere at danne sig indtryk af samtalepartnerne, dvs. svækker det 'sociale nærvær' ('social presence') (Short et al. 1976): diskussionen vil blive mindre konsensussøgende og mindre hæmmet af hensyn til social status, hvilket kan give plads til flere alternativer og gøre deltagerne tilbøjelighed til at acceptere dårlige argumenter uden kritik (Sproull \& Kiesler 1991), og hensynet til selve det faglige indhold i diskussionen vil veje tungere end de sociale processer ((Short et al. 1976)) . Hvis man skelner mellem to forskellige funktioner i kommunikationsmedier, på den ene side rollen som 'kanal' mellem kommunikationspartneren, og på den anden side rollen som et 'tegn', der refererer til et indhold, kan man sige, at mediet her qua svagere kanal-funktion (færre 'cues' og mindre 'feedback') skaber en social distance og retter større opmærksomhed mod 'tegn'-funktionen. Endelig, som en sidegevinst, får underviseren bedre mulighed for at følge med i læreprocessen.

Den nye model, baseret på en skriftlig netbaseret diskussion, blev indført dels efter inspiration fra erfaringer fra det engelske Open University Business School (Salmon 2002), dels som reaktion på erfaringer med den hidtidige 'model' på MCC-uddannelsen. Tidligere skulle deltagerne skrive en gruppeopgave i den mellemliggende periode inden næste internat. Grupperne kunne så bruge samarbejdssystemet BSCW som fælles platform, til at dele og diskutere dokumenter. Nogle undervisere oplevede en række ulemper ved denne model: ofte havde deltagerne ikke forberedt sig til selve internatet, hvilket gjorde det svært at føre en dialog på et fagligt niveau; grupperne brugte kun i begrænset omfang BSCW, men foretrak at mødes ansigt til ansigt; og arbejdsindsatsen var oftest koncentreret omkring deadline op til næste internat.

Med den nye model får BSCW en central rolle, og der er tale om stærkere styring fra underviserens side. I stedet for at skrive en opgave sammen i perioden mellem to internater, skal kur- 
susdeltagerne deltage i et såkaldt netseminar, hvor de dels skal skrive individuelle indlæg (løse en opgave, besvare nogle spørgsmål, diskutere et emne), dels kommentere og diskutere hinandens indlæg, og der er et par deadlines i løbet af hver uge. Man kan invende, at denne 'diskussionsform' er mindre forpligtende, sammenlignet med en traditionel projektmodel, hvor deltagerne er tvunget til at diskutere sig frem til enighed. På den anden side kan projektmodellens krav om et færdigt resultat til en bestemt deadline ofte medføre, at irriterende kritiske argumenter bliver kvalt (Sproull \& Kiesler 1991). Desuden kan man sige, at teknologien ved som sagt at muliggøre en ny kommunikationsform - skrift + dialog - opgraderer en klassisk undervisningsform: før projektmodellens indførelse var universitetsundervisningen (på ikketekniske fag) i høj grad baseret på diskussion med udgangspunkt i en tekst, og den mundtlige diskussion var hæmmet af, at det var svært at huske hele diskussionen - og måske især de argumenter, som man ikke forstod i første omgang. Teknologien har nu reduceret denne svaghed ved diskussionsmodellen ved at gøre det lettere at fastholde og vende tilbage til argumenterne.

Denne fokus på diskussion frem for produkt har sandsynligvis også betydning for gruppernes størrelse. Diskussionerne i det skriftlige seminar må gerne foregå i grupper på seks - syv personer eller mere: da grupperne ikke skal samarbejde om et fælles produkt (hvor gruppen helst skal være mindre), men netop skal diskutere indbyrdes, er det muligt og formodentlig en fordel at have lidt større grupper for at opnå en vis spredning og undgå for meget 'symbiose' (der kunne hæmme diskussionen).

Der er ikke foretaget en egentlig evaluering af selve den nye model (kun af de enkelte kurserne), men mange af deltagerne på uddannelsen virker generelt tilfredse med selve den nye model baseret på et skriftligt forløb. De finder det nemmere at 'tage sig sammen', når der er tale om mindre opgaver, også selv om der er flere deadlines (sammenlignet med en enkelt deadline for et større projekt). Det er lettere at afsætte en times tid om aftenen til en overskuelig opgave end at overskue færdiggørelsen af et større projekt. Desuden er de ofte direkte motiveret til svare på andres indlæg.

Der er selvfølgelig også en række ulemper eller faldgruber med den nye model. Det kan være svært at indhøste de ovennævnte fordele ved medieret kommunikation, hvis den manglende sociale kontakt ('social presence') er direkte hæmmende for overhovedet at etablere en dialog. Og det 'fattige' medium - mangel på nonverbale signaler og hurtige feedback-muligheder kan gøre det sværere at afklare misforståelser, f.eks. i forbindelse med store forskelle i faglig baggrund og forståelsesramme (Daft \& Lengel 1986). Den mundtlige dialog har en række muligheder for at afklare misforståelser og 'reparere' kommunikationen undervejs (Hutchby 2001), og derfor kan der være en fare for, at deltagerne i en skriftlig diskussion - uden de samme muligheder for løbende justering af kommunikationen - 'låses fast' i en bestemt fortolkning og/eller 'taler forbi hinanden' over længere tid (det samme gælder i øvrigt kommunikationen mellem deltagerne og underviseren).

Umiddelbart kan man indvende, at 'misforståelser' er mindre problematiske, når det ikke drejer sig om at levere et fælles produkt: 'misforståelser' kan være kreative og åbne for nye perspektiver, og i øvrigt gælder det netop for tekster, at forfatteren/afsenderen ikke har eneret over deres betydning og fortolkning (Gadamer 1960) - teksten kan således have et relevant indhold, som afsenderen ikke havde intenderet. Ikke desto mindre kan det selvfølgelig være 
problematisk for diskussionen, hvis deltagerne ligefrem 'taler forbi hinanden' eller ikke forstår de 'intenderede' argumenter - og derfor kan man formode, at der i løbet af den skriftlige fase opstår et behov for en mundtlig dialog.

Sagt på en anden måde: for at afklare tvetydigheder og misforståelser, kan der være behov for at dreje opmærksomheden væk fra 'indholdet' og over mod kommunikationspartnerens bagvedliggende forudsætninger, hvilket stiller større krav til den førnævnte 'kanal'-funktion. På den anden side er formålet stadig en 'intellektuel' afklaring med fokus på perspektiver, forudsætninger og argumenter snarere end følelser og etablering af sociale relationer.

\section{Mundtlig dialog på 'virtuelle møder'}

Behovet for en mundtlig dialog kan så opfyldes ved hjælp af et 'virtuelt' møde baseret på synkron lyd, hvor man bedre vil være i stand til hurtigt at identificere og afklare misforståelser og tvetydigheder på forskellige niveauer i diskussionen - 'forandre forståelse inden for et kort tidsinterval', jf. teorien om 'media richness' (Daft \& Lengel 1986; Huber \& Daft 1987) - og følge op på udvalgte emner. Ud fra disse overvejelser har jeg i efteråret 2004 gennemført et uformelt eksperiment, hvor jeg supplerede den førnævnte skriftlige diskussion i to forskellige kurser med et virtuelt møde. Men før jeg beskriver selve eksperimentet vil jeg uddybe argumentationen ved at pege på nogle flere karakteristika ved den mundtlige dialog.

Den mundtlige dialog er først og fremmest karakteriseret ved en umiddelbar feedback-mulighed, der giver mulighed for at stille hurtige opklarende spørgsmål - desuden kan lyden af deltagernes stemme give ekstra informationer, både om deres egne udsagn og deres reaktion på andres indlæg (Culnan \& Markus 1987;Thompson 2001).

Et andet væsentligt kendetegn ved den mundtlige dialog er, at den er lineær og analog: folk taler én ad gangen og helst ikke i munden på hinanden. Det betyder på den ene side, at alle deltageres opmærksomhed på samme tid er rettet mod det, der bliver sagt, og på den anden side at samtalen er opbygget af 'taleture', hvor 'turtagningen' må reguleres (Drotner et al. 1996) - på et traditionelt møde sker det vha. en talerrække og en ordstyrer, og i mindre formelle sammenhænge vha. en række sociale regler, der i høj grad er baseret på nonverbale signaler.

Den begrænsede taletid bliver ofte karakteriseret som en ulempe, der til gengæld ophæves med asynkron skriftlig kommunikation, hvor turtagning enten er irrelevant (fordi indlæggene slet ikke kommer samtidig) eller unødvendig (fordi man netop - i princippet - godt kan 'tale i munden på hinanden'). Dette betyder bl.a., at flere kan komme til orde, fordi de ikke skal overvinde turtagningens sociale filter (Sproull \& Kiesler 1991). Ikke desto mindre er der også ulemper eller udfordringer forbundet med at 'overvinde' den mundtlige dialogs turtagning. For det første har skriften jo arvet det talte sprogs linearitet, og derfor kan man sige, at 'nissen flytter med' i form af problemet med at overskue en mængde (samtidige) tekster - dog burde hypertekst-teknologien her byde på nogle nye muligheder for at knytte kommentarer til bestemte steder i andres tekster vha. forskellige typer links og oprette 'tråde' i diskussionen. For det andet kan det også være en ulempe, at deltagernes opmærksomhed i elektronisk kommunikation er spredt og ufokuseret - og selvom alle kan 'tale', er det ingen garanti for, at man faktisk bliver 'hørt'. Her har den mundtlige dialog som sagt den styrke, at den i princippet påkalder alle deltagernes opmærksomhed - der er en større social forpligtelse til at følge med. 
På det virtuelle møde bruger vi ikke webcams og råder derfor ikke over visuelle signaler om modtagerne (eller deres baggrund). Rent teknisk svarer det således til et almindeligt telefonmøde, dog med en væsentlig undtagelse. Telefonsamtalen er bundet til den mundtlige dialog alene og kan ikke understøtte brug af visuelle input, såsom f.eks. brug af tavle eller powerpoint i et undervisnings- eller mødelokale. Man kan sige, at telefonen udelukkende understøtter 'kanal'-funktionen, men ikke 'tegn'-funktionen i kommunikationen (udover ved at gengive talen). På det 'virtuelle' møde har vi derimod også har mulighed for at se det samme skærmbillede - og deltagerne kan derfor følge med, når underviseren scroller frem og tilbage i en tekst, eller surfer rundt med browseren. Det gør det f.eks. let at diskutere et tekstuddrag eller evt. supplere med grafisk illustration. Computermediet gør det dermed lettere at anvende forskellige 'sprog' i kommunikationen, hvad enten det drejer sig om 'rigere' data i forhold til det talte sprog i form af billeder, eller omvendt et mere formaliseret sprog, f.eks. med vægt på logiske udsagn eller grafisk illustration af komplekse sammenhænge.

Det er nærliggende at sammenligne den medierede mundtlige dialog - både det traditionelle telefonmøde og det computermedierede - med at mødes ansigt til ansigt. I undervisningssammenhænge vil man således stå over for valget mellem at lade kursusdeltagerne møde op til en fælles lektion eller afholde et (computermedieret) telefonmøde. I første omgang synes der at være tale om et trade-off, hvor man balancerer fordelene ved at holde mødet 'hjemmefra' over for ulemperne ved et 'fattigere' medium. En åbenlys fordel er selvfølgelig den økonomiske i at spare tid og omkostninger på at rejse til og fra et fælles undervisningslokale. Det er vigtigt for f.eks. masterstuderende, for hvem tiden er en knap ressource, pga. både fuldtidsarbejde og familieliv. En anden fordel er, at deltagerne har adgang til deres private arbejdsplads og dermed mulighed for at slå op i bøger, noter, internet etc. (men også en fare for, at mødet taber i konkurrencen om deltagernes opmærksomhed).

Disse fordele skal til gengæld som nævnt afvejes mod visse mangler/ulemper sammenlignet med at mødes ansigt til ansigt. Manglen på visuelle signaler kan gøre det umuligt for taleren at understrege sine ord ved hjælp af gestik og gør det samtidig sværere at tyde tilhørernes reaktion (man kan ikke se dem nikke forstående, ryste indigneret på hovedet - eller få et 'tomt udtryk' i ansigtet). Frem for alt kan det blive sværere at regulere 'turtagningen' i dialogen, som normalt håndteres ved hjælp af nonverbale signaler - såsom at række hånden op for at få ordet, nikke til den næste taler etc. Desuden er det umiddelbart sværere for deltagerne at etablere kontakt med hinanden udenom den 'officielle' talerrække, som de ellers ville kunne gøre ved at hviske eller gestikulere indbyrdes. På den anden side byder computermediet her, i modsætning til telefonmødet, på nogle unikke muligheder for 'perifer kommunikation', da de ofte netop kan 'hviske' ved at chatte én-til-én.

På trods af disse ulemper vil det dog være misvisende blot at betragte denne type 'mundtlig dialog' som 'forarmet kommunikation'. Det er ellers nærliggende at opfatte det at være fysisk til stede, ansigt til ansigt, som den ideelle situation og i det lys at betragte det computerbaserede telefonmøde som primært en 'nødløsning' med henblik på at spare ressourcer - hvor mediet betragtes som et hæmmende 'filter' mellem deltagerne, der må accepteres som et nødvendig onde. Men som antydet tidligere, så kan det måske stadig være en fordel at undgå 'fuld' 'social presence' for at rette opmærsomheden mod saglige og faglige forudsætninger frem for sociale relationer (Short et al. 1976). Med andre ord kan der være nogle særlige fordele ved den såkaldt 'forarmede' kommunikation. også selv om vi på det virtuelle møde beskrevet i 
denne artikel taler om en kommunikation, der er rettet mod at afklare misforståelser, bl.a. ved at afdække bagvedliggende forudsætninger og perspektiver, hvilket i princippet kræver en større opmærksomhed mod de andre deltagere.

\section{Udfordre 'forforståelsen' - en pædagogisk udfordring}

Efter at have argumenteret for, at den mundtlige dialog kan være velegnet til at afklare misforståelser, vil jeg pege på, hvornår og hvorfor sådanne misforståelser kan opstå i bl.a. undervisningssammenhænge - og dermed give et bud på, hvornår der kan være et behov for en mundtlig dialog. Jeg vil således hævde, at en skriftlig diskussionsfase som den, der er beskrevet ovenfor, i høj grad vil aktivere deltagernes individuelle forståelsesprocesser snarere end en fælles kollektiv læreproces - og dermed forstærke behovet for, at deltagerne på et tidspunkt må investere tid i at forstå hinandens baggrund.

Dette behov har nemlig sit udspring i en grundlæggende udfordring for undervisningen (og underviseren) at 'møde folk dér, hvor de er', dvs. tage udgangspunkt i, eller knytte an til de forudsætninger og 'forforståelser', deltagerne har i forvejen. Dette er især relevant for masteruddannelser, hvor deltagerne normalt har både praktiske erfaringer fra arbejdslivet og en længerevarende uddannelse. Det er en indlysende fordel, når undervisningen kan 'bygge videre' på deltagernes eksisterende forudsætninger, men det kan på den anden side være en stor udfordring, hvis kursets emne på en eller anden måde er i modstrid med deltagernes forforståelse. Her må underviseren være opmærksom på, at deltagerne enten 'har svært ved at forstå' emnet, eller hvad der måske er værre, misforstår emnet, fordi forforståelsen fører til en bestemt fortolkning. En anden fare er, at deltagerne godt nok forstår emnet i undervisningsforløbet, fordi vedkommende i denne kontekst formår at abstrahere fra hverdagens rutiner (og perspektiver), men at denne forståelse siden 'fordamper' eller bliver inaktiv, når kurset er overstået, og hverdagen igen melder sig.

En måde for underviseren at håndtere de forskellige individuelle erfaringer og forforståelser på kan være at 'overrule' dem ved at indlede kurset med at etablere et fælles fundament, f.eks. ved at indlære nogle centrale grundbegreber. Fordelen med denne tilgang er, at man derved hurtigt skaber forudsætninger for en fælles læreproces. Men en ulempe kan som sagt være, at det, man lærer på kurset, er svært at huske eller 'aktivere' senere, fordi man har svært ved at relatere det til hverdagens erfaringer eller til sin eksisterende 'forståelseshorisont'.

En anden måde kunne være at satse bevidst på at mobilisere deltagernes forforståelse, f.eks. ved at tage udgangspunkt i, hvilke konkrete erfaringer der fik dem til at vælge det pågældende kursus. Man kan f.eks. give dem lejlighed til at formulere deres forståelse af nogle af de emner eller eksempler, som undervisningen vil berøre. Faren ved denne tilgang er, at deltagerne får 'rejst paraderne', dvs. at deres forforståelse ved at blive legitimeret i undervisningsforløbet kan blive blokerende over for 'kontroversielle' pointer i kurset eller blive styrende for deres forståelse af pointer (hvilket kan føre til misforståelser). Men fordelene er bl.a., at de vil kunne give et bedre modspil i dialogen med underviseren, og underviseren vil blive tvunget til i højere grad at argumentere for sine pointer og evt. reflektere over sine egen antagelser. Og ambitionen er at opnå ny indsigt ved at rokke ved deltagernes forforståelse, så de bliver i stand til at se nogle af deres egne erfaringer i et nyt lys. 
Det skal dog ikke forstås på den måde, at deltagerne i princippet skal igennem en 'renselsesproces', hvor de skal give afkald på deres hidtidige 'vrangforestillinger'. Ved at mobilisere forforståelsen er der som sagt også mulighed for at få formuleret nogle relevante modargumenter til, og perspektiver på, underviserens udspil - processen kræver en åbenhed fra begge parter.

Med dette afsnit har jeg villet pege på, hvordan der i undervisningsforløbet kan blive behov for en proces, der indebærer en dybere afklaring af forskellige forforståelser, f.eks. med henblik på at afklare misforståelser - en proces, der i høj grad vil have gavn af en mundtlig dialog. Og heldigvis er der efterhånden gode tekniske muligheder for at etablere en mundtlig dialog via computermediet, hvilket illustreres af de erfaringer, der beskrives i det følgende.

\section{Teknologiske karakteristika: internet-telefoni + fælles skærmbillede}

Vi har holdt os til en meget simpel teknologi på de virtuelle møder (se nedenfor). Dels måtte vi tage hensyn til, at enkelte deltagere brugte Apple-maskiner, og flere af konferencesystemerne er endnu kun designet til PC-platform. Dels var en enkelt deltager tilsluttet internettet via modem og havde derfor kun en meget begrænset båndbredde.

Vi valgte i første omgang at bruge programmet Skype, der har en meget høj lydkvalitet og giver mulighed for at holde telefonmøder med op til fem personer (se appendiks A for en nærmere beksrivelse af Skype og Glance). En fordel ved Skype er, at der næsten ikke er mærkbar forsinkelse på lyden, i modsætning til flere af de konferencesystemer vi har stiftet bekendtskab med. Dette var også afgørende for valget, da vi på grund af den korte tidsramme helst ville undgå unødvendige tilvænningsproblemer (forsinkelse på lyden opleves som meget forstyrrende i forhold til en normal mundtlig dialog). Desuden er det et program, som deltagerne kan bruge i andre sammenhænge og let kan vænne sig til. Udover internet-telefoni kan Skype bruges til at 'chatte' én-til-én og kan desuden vise, hvilke kontaktpersoner der er 'online'.

Der er selvfølgelig også visse ulemper ved Skype. Først og fremmest er grænsen på fem personer upraktisk, især i lyset af de førnævnte overvejelser om gruppestørrelse i denne undervisningsform - det svarer til en gruppe på fire personer, når underviseren også deltager i mødet. Desuden rummer Skype ingen faciliteter til ordstyring (dvs. regulering af turtagning), men det problem er formodentlig mindre, netop pga. førnævnte begrænsning: turtagning med fem personer er trods alt overskueligt. Endelig understøtter Skype selvfølgelig ikke på nogen måde en fælles 'tavle' og må derfor suppleres med andre faciliteter.

Til dette formål valgte vi programmet Glance, der så at sige 'broadcaster' abonnentens skærmbillede til et ubegrænset antal deltagere, der blot skal bruge et link og et kodeord for at få adgang. De kan vel at mærke kun se, hvad der foregår på abonnentens computerskærm og har altså ingen mulighed for selv at foretage sig noget. Det er med andre ord en simpel facilitet, der gør det muligt at 'dele' (næsten) alt, hvad der kan foregå på en computerskærm: både tekst og grafiske virkemidler i form af browsere, tekstbehandling, præsentationsgrafik, tegneprogrammer etc. Det kan være en fordel frem for mange konferencesystemer, der kun tilbyder applikationsdeling af browsere og Powerpoint. En af ulemperne er så, at der netop ikke er tale om egentlig 'applikationsdeling', da alle andre deltagere end selve Glance-abonnenten blot er tilskuere. En anden ulempe er, at det kræver en stor båndbredde at transmittere et helt skærm- 
billede, hvilket bl.a. viste sig at være et problem for en deltager med modemforbindelse - og løsningen vil næppe være velegnet til at vise video.

Som sagt brugte vi denne løsning - Skype + Glance - på alle møderne, men vi undersøgte andre muligheder $\mathrm{i}$ anden omgang, primært for at omgå begrænsningen på fem personer. Valget faldt på konferencesystemet Ivocalize, der bl.a. rummer en fælles browser, en talerrække med ordstyrer, og en mulighed for at optage dialogen. Lyden er dårligere end Skype og med større forsinkelse, men til gengæld kræver denne løsning mindre båndbredde. Pga. tekniske problemer og afbud gik vi imidlertid tilbage til den 'kendte' løsning.

\section{Mundtlig opsamling på det skriftlige seminar}

Vi afholdt som nævnt 'virtuelle møder' med ovennævnte teknologi i forbindelse med to forskellige kurser. I begge tilfælde blev mødet afholdt efter afslutningen af et skriftligt seminar (mere herom senere). I første omgang efter et kursus i computerbaseret videndeling, hvor den skriftlige diskussion foregik i tre grupper á fire - fem personer. Der blev planlagt tre møder (et med hver gruppe) af hver en times varighed. Alle møderne foregik samme aften i forlængelse af hinanden (da underviseren skulle deltage i alle tre).

Det næste møde blev holdt som opsamling på et kursus i Elektronisk Demokrati og Digital Forvaltning. Dette kursus foregik over tre uger. Det indledtes med en 'almindelig' lektion ansigt-til-ansigt i form af en introducerende forelæsning, efterfulgt af tre forskellige aktiviteter af ca. en uges varighed. Det virtuelle møde blev afholdt en uges tid efter det skriftlige seminar. Her var af forskellige grunde færre deltagere, og der blev kun holdt et enkelt møde, som varede halvanden time.

\section{Erfaringer fra forløbet}

\section{Det skriftlige seminar: fra 'eksamensspørgsmål' til diskussionsoplæg}

Da det virtuelle møde som sagt blev afholdt på baggrund af det skriftlige seminar, kan det være en fordel at forstå udformningen af dette og de ændringer, der blev indført som reaktion på erfaringerne med det første kursus - dels på grundlag af mit eget indtryk af forløbet, dels på grundlag af deltagernes kommentarer undervejs og i den efterfølgende evaluering. Ændringerne vedrører især to forskellige 'parametre' i tilrettelæggelsen af kurset, dels designet af de enkelte aktiviteter i forløbet, dvs. primært udformningen af spørgsmål, dels underviserens rolle i forløbet.

På det første kursus stillede jeg relativt detaljerede spørgsmål, der skulle 'dirigere' deltagerne rundt i de forskellige hjørner af pensum. Det lykkedes da også, men ikke uden problemer: på den efterfølgende evaluering sagde deltagerne, at de følte sig mere 'styrede' og var mindre motiverede (og motivationen er vigtig for at opnå en diskussion) sammenlignet med et tidligere kursus efter samme model. Svarene tog form af lange, relativt lukkede indlæg, der i mindre grad indbød til diskussion.

Hvad underviserens rolle angik, var min deltagelse begrænset til en forsigtig regulering af indlæggenes omfang, samt en opsamling på hver aktivitet (af en uges varighed) inden for hver gruppe. Denne opsamling krævede grundig bearbejdning, og blev først 'uploaded' et par dage efter, at deltagerne var gået i gang med den næste aktivitet. Resultatet var tilsyneladende, at disse opsamlinger ikke blev læst (i hvert fald ikke særlig grundigt). Efter forløbet gav flere 
deltagere udtryk for, at jeg hellere skulle bruge ressourcerne på at indgå i selve diskussionen, evt. ved at udpege relevante, men hidtil upåagtede temaer i deltagernes indlæg, med henblik på at generere refleksion og diskussion. Problemet med dette forslag er dog, at jeg meget nødig vil styre diskussionen for meget, og helst give deltagerne god tid til selv gribe fat i de emner de ønsker at diskutere.

Der er selvfølgelig en sammenhæng mellem de to parametre: udformningen af spørgsmål, og underviserens rolle i diskussionen. Hvis jeg som underviser stiller relativt åbne spørgsmål, vil der til gengæld være et behov for i højere grad at moderere diskussionen, dvs. overvåge, om deltagerne faktisk berører nogle af de temaer, som jeg finder centrale.

Derfor valgte jeg på det næste kursus at formulere meget åbne spørgsmål, men til gengæld satse på at overvåge diskussionen og evt. bidrage med spørgsmål undervejs - spørgsmål, der på den ene side reagerer på de eksisterende indlæg og altså ligger i forlængelse af deltagernes diskussion, men på den anden side skærper opmærksomheden på udvalgte temaer. Her kan der opstå et problem med de tidsmæssige rammer for kurset: når hver enkelt aktivitet typisk varer en uge, og jeg som underviser først vil reagere efter deltagernes egne indlæg, bliver der ikke meget tid til, at deltagerne kan reagere på mine indlæg. Som løsning lagde jeg op til, at diskussionerne skulle være 'åbne' også efter aktivitetens afslutning, dvs. med mulighed for, at deltagerne senere kunne vende tilbage og fortsætte en tidligere diskussion.

Generelt var det skriftlige seminar på det næste kursus mere vellykket. Deltagerne var klart motiverede til at bidrage og indgå i en diskussion. Til gengæld oplevede jeg, at de fleste indlæg i den første aktivitet (med udgangspunkt i konkrete forslag til e-demokrati) ikke rigtig gjorde brug af litteraturen, og derfor følte jeg et behov for at moderere diskussionen ved at gøre opmærksom på dilemmaer og kritiske spørgsmål. Desværre lykkedes det ikke at opnå en forlænget diskussion inspireret af mine indlæg. Mine indlæg blev godt nok læst, og deltagerne foretrak tilsyneladende sådanne konkrete kommentarer til udvalgte diskussioner (frem for en større omsamling i et selvstændigt dokument, hvor det var sværere at se konteksten), men der var ikke nogen, der reagerede på dem. Det kan skyldes, at tidsrammen for dette kursus var meget snæver - knap tre uger i alt - og at folk var mere optaget af næste uges tema. Til gengæld kom nogle af mine indlæg til at danne baggrund for diskussionerne på det virtuelle møde, og det skyldes måske, at emnerne var mere velegnede til en mundtlig diskussion, fordi de ofte drejede sig om at konfrontere deltagernes forforståelse.

\section{Det virtuelle møde: behov for en klar dagsorden}

Teknologien var i princippet brugervenlig og nem at tage i anvendelse, om end der var visse begyndervanskeligheder. I den første 'runde' (tre møder på samme aften) var det i flere tilfælde vanskeligt at komme ordentligt i gang - især når der skulle starte et nyt møde efter en times tid. I én gruppe var der problemer med en deltager koblet op med modem: vedkommende faldt ud flere gange, formentlig på grund af Glance, og måtte til sidst opgive(s). I den sidste gruppe var der problemer med lyden fra et par af deltagerne, men det var ikke værre, end at vi efterhånden kunne koncentrere os om selve diskussionen. På mødet i den sidste 'runde' var der til gengæld ingen tekniske problemer. Generelt er det mit indtryk, at lydkvaliteten på Skype er meget høj, og selvom andre dog har oplevet svingende kvalitet, er teknologien god nok til, at jeg ikke vil bruge mere tid på praktiske problemer, men i det følgende kan fokusere på de erfaringer, der er forbundet med teknologiens grundlæggende potentiale (eller 'affordances'). 
Først og fremmest lader det til, at der er et særligt behov for en dagsorden og et klart udspil til mødet. Før den første runde havde jeg en forestilling om, at mødet ville opfylde et 'opsparet' behov for en mundtlig dialog om temaer fra det skriftlige seminar - dvs. at mødet kunne baseres på, at deltagerne af sig stillede spørgsmål eller tog udvalgte diskussioner op. Det viste sig at være en naiv forestilling: der opstod ikke af sig selv nogen diskussion. Det kan der være flere grunde til: 1) Måske er det uafhængigt af situationen og teknologien: enhver form for undervisning kræver forberedelse, selv når det blot drejer sig om en opsamling. Ikke desto mindre kunne man formode, at netop den skriftlige dialog ville forstærke behovet for afklaring af visse punkter. 2) Eller det skyldes kursets konkrete udformning: de spørgsmål, som det skriftlige seminar var baseret på, viste sig at være mindre egnede til en åben diskussion mellem deltagerne. Der var som sagt tale om relativt detaljerede spørgsmål, som snarere resulterede i lukkede 'essays'; og når der ikke i det foregående netseminar havde været en livlig diskussion, var det også sværere at tage hul på en diskussion på det virtuelle møde. 3) Men det kan også hænge sammen med selve teknologien: f.eks. at mediet (mangel på visuelle signaler) kun giver en svag fornemmelse af 'nærvær' (social presence), hvilket reducerer sandsynligheden for, at en diskussion opstår spontant. Dette peger på, at der er større behov for styring i form af en dagsorden, eller i det mindste et udspil fra underviseren.

Der er formodentlig tale om en kombination af disse tre faktorer: 1) generelle krav til undervisning; 2) særlige forhold ved emnet og det skriftlige seminar; 3) teknologiske rammer (medie-karakteristika). Heldigvis havde jeg et udspil i baghånden, i form af et udkast til en opsamling på den sidste uges 'diskussion' - og på det sidste møde (i anden runde) havde jeg gjort mig mere klare tanker om, hvad jeg ville bruge mødet til.

I anden omgang benyttede jeg således lejligheden til at forfølge et emne (indflydelse vs. repræsentativt demokrati), der som tidligere nævnt var blevet forsømt eller overset i løbet af det skriftlige seminar, og som krævede en dialog for at spore sig ind på forskellige betydninger af det samme begreb. Dermed fik jeg også mulighed for at argumentere en pointe igennem. Ved at tage sådan et emne op på mødet fik jeg mulighed for at reagere på deres egne argumenter og besvare opklarende spørgsmål. Jeg kan i øvrigt tilføje, at selvom jeg havde forberedt denne diskussion, blev den faktisk 'sparket i gang' ved, at en af deltagerne reagerede på mine skriftlige kommentarer, dvs. at den i denne omgang faktisk opstod som reaktion på den skriftlige fase og således kunne ses som et behov for en mundtlig dialog i forlængelse af den skriftlige. Jeg siger ikke, at det ikke er muligt at opnå sådan et resultat med den skriftlige dialog, men det ville have taget meget længere tid (med kun to deadlines om ugen) - især for det sidste kursus var der tale om en meget begrænset tidsramme. Det handler dog også om, at jeg for dette udvalgte emne gerne ville styre dialogen: jeg vil gerne have en form for reaktion fra alle deltagerne, en fornemmelse af at de har 'forstået' pointen.

Et væsentligt emne vedrører brugen af den fælles 'tavle' - fordi det netop er computermediets særlige styrke, sammenlignet med et traditionelt telefonmøde. På de første tre møder benyttede jeg mig ikke systematisk af muligheden: på et af møderne tog jeg direkte udgangspunkt i et dokument, hvor jeg havde plukket citater, hvilket gjorde det nemmere for deltagerne at følge med; på et andet lagde jeg i stedet op til, at deltagerne kunne stille uddybende spørgsmål - og på grund af diverse tekniske problemer, samt tidspres fra det efterfølgende møde, kom vi aldrig rigtig i gang. 
På det sidste møde (i anden runde) havde jeg til gengæld samlet nogle pointer på stikordsform, og dette dokument kom også til at fungere som dagsorden. På den måde kom den fælles 'tavle' bl.a. til at understøtte det førnævnte behov for en dagsorden. Og da en af deltagerne ønskede at diskutere en af de kommentarer, jeg tidligere havde skrevet til hans indlæg, kunne vi gøre det ved at browse rundt i BSCW - og samtidig knytte an til en af de pointer jeg havde forberedt. Vi benyttede med andre ord lejligheden til at gå ind i BSCW og diskutere formuleringer fra netdiskussionen. Det illustrerer dels en fordel ved den skriftlige form, muligheden for at genkalde argumenter fra diskussionen (selvom de skriftlige argumenter selvfølgelig ikke er éntydige), dels fordelen ved at supplere det mundtlige 'telefonmøde' med en fælles 'tavle'.

Endelig bør jeg dog bemærke, at jeg ikke selv er den bedste til at vurdere betydningen af at følge med på skærmen - det er jo mig, der 'styrer', og de andre, der følger med. Flere af deltagerne bemærkede dog også bagefter, at de havde haft glæde af den 'fælles tavle' - en hævder således, at det i høj grad understøtter dialogen.

Som tidligere nævnt kunne man frygte, at dialogen ville være hæmmet af manglen på yderlige 'nonverbale cues', såsom ansigtsudtryk, omgivelser, social kontekst etc. Dette burde f.eks. gøre det sværere at regulere turtagning og tyde tilhørernes reaktioner.

Min oplevelse var, at det godt nok var lidt mere besværligt at håndtere en talerrække (man kan ikke se folk række hånden op, og man kan ikke pege på den næste taler), men problemet var overskueligt med så få deltagere. Til gengæld føltes 'tavshed' fra tilhørerne mere frustrerende. Jeg oplevede det som et advarselssignal, når jeg kunne tale i længere tid uden at høre reaktioner fra deltagerne. Det er selvfølgelig også et problem i en almindelig ansigt-til-ansigt undervisningssituation (især hvis man ønsker dialog), men der kan man i det mindste tyde nogle nonverbale reaktioner såsom ansigtsudtryk, nik med hovedet, etc.

\section{Opsamling/konklusion}

Teknologien tilbyder efterhånden let tilgængelige og billige muligheder for at inddrage virtuelle møder i fjernundervisningen. Hvis man skal have glæde af computerbaserede telefonmøder, bør man tage udgangspunkt i den mundtlige dialogs særlige fordele (og ulemper) med henblik på at vurdere, hvornår og hvordan de kan tjene et formål i undervisningsforløbet. Den mundtlige dialog er velegnet til løbende at 'reparere' kommunikationen og afklare misforståelser. Dette vil man til dels kompensere for i den skriftlige kommunikation ved at gøre sig større umage med formuleringen for på forhånd at undgå tvetydighed. Men dels er det principielt umuligt at styre andres læsning, dels bliver det sværere at gardere sig mod uønskede fortolkninger, hvis man skriver kortfattet om komplekse emner til folk med forskellige baggrunde og forståelsesrammer.

Efter- og videreuddannelse retter sig ofte mod folk med forskellige uddannelsesbaggrunde og ballast af praktiske erfaringer, og det stiller underviserne over for en udfordring. Der er på den ene side et potentiale for at knytte an til deres eksisterende viden og erfaringer, men der er også en fare for, at deres forståelsesramme i stort omfang styrer deres læsning - og dermed en fare for misforståelser på et 'ybere plan. Derfor kan der opstå et behov for en mundtlig kommunikation med henblik på at opnå en afklaring om de forskellige tolkninger, der er i spil. 
Jeg har i det konkrete tilfælde eksperimenteret med et virtuelt møde i forbindelse med en anden computermedieret undervisningsform, en skriftlig diskussion. Jeg vil hævde, at det 'virtuelle' møde ligefrem kan udfylde et 'hul' i forhold til det skriftlige seminar. Tidsrammen på det skriftlige seminar gør det sværere at gennemføre en diskussion, der kræver høj grad af dialog f.eks. med henblik på afklaring af misforståelse; men også en dialog, der sigter på at udpege en pointe, der er blevet forbigået i det skriftlige seminar ...

Behovet for en mundtlig opsamling forstærkes som sagt, når det skriftlige seminar er baseret på relativt åbne spørgsmål, der inviterer deltagerne til at følge temaer efter egen interesse, frem for at styre dem gennem udvalgte problemstillinger. Med denne åbne form vil der være et større behov for, at underviseren kan samle op og f.eks. etablere en rød tråd, eller trække en pointe frem. Men det skal være en opsamling, der er åben for dialog - det er jo netop styrken ved dette medium. Og i denne situation vil deltagerne typisk være velforberedte gennem det skriftlige seminar og også motiverede for både at argumentere for deres synspunkter (forsvare deres egne indlæg) og forstå kritik og kommentarer.

\section{Videre diskussion}

Kunne man også bruge denne teknologi til andre dele af undervisningen, f.eks. den introducerende forelæsning? En af deltagerne (med bopæl i Jylland) mente efter kurset, at denne forelæsning sagtens kunne være afholdt på samme måde. Som underviser er jeg ikke så glad for tanken om at skulle holde en egentlig 'fjern-forelæsning' - jeg frygter bl.a., at det i endnu højere grad end en normal forelæsning vil føles som en timelang enetale uden feedback fra tilhørerne. Forelæsningen er en undervisningsform, der i forvejen er pacificerende og 'asocial', og jeg frygter, at den vil falde helt fra hinanden, hvis man reducerer de 'visuelle signaler'. I modsætning til f.eks. en opsamling, der i højere grad lægger op til diskussion mellem deltagerne, når først diskussionen er i gang, betyder manglen på nonverbale signaler mindre. Men måske er dette primært et problem for underviseren, der ikke bryder sig om at forelæse i en tom sal, hvorimod deltagerne ikke føler det som så stort et problem? I så fald kan man selvfølgelig spørge, om der overhovedet er nogen grund til at have en synkron transmission og understøttelse af dialog. Hvis der ikke er reelt behov for opklarende spørgsmål og diskussion, er der vel ingen grund til at skyde gråspurve med kanoner, og deltagerne kunne lige så godt få forelæsningen på bånd (eller en mp3-fil)?

Et andet diskussionspunkt vedrører antallet af deltagere. I det konkrete tilfælde sætter teknologien nogle snævre begrænsninger: max. fem personer i et Skype-telefonmøde, dvs. underviseren og fire deltagere. Det er selvfølgelig muligt at finde en teknologisk løsning, der tillader et større antal deltagere, men det vil nok være uhensigtsmæssigt at øge antallet voldsomt, da det så kan blive svære at etablere en dialog. Dette hensyn gælder selvfølgeligt uafhængigt af teknologien, jf. mine overvejelser i starten af artiklen. Selvom diskussionen vil have gavn af flere deltagere end ved almindeligt gruppearbejde, så vil der stadig være en øvre grænse: jo flere deltagere, jo sværere bliver det at etablere en dialog, hvor alle deltager aktivt. Men problemerne kan forventes at være større med denne teknologi: den aktive deltagelse i dialogen er med til at fastholde fornemmelsen af 'nærvær', og hvis deltagere falder helt ud af dialogen, kan det blive svære for dem at fastholde koncentrationen. 
Hvis jeg har ret i, at man under alle omstændigheder bør nøjes med et begrænset antal deltagere på hvert møde, er det nærliggende at spørge, om det så ikke er for ressourcekrævende. Hvis underviseren skal holde møder af min. en times varighed med grupper af max. ti deltagere, er der tale om en større investering, hvis man underviser større hold. Det kan f.eks. være en slem skuffelse for dem, der ser fjernundervisning som en ressourcebesparende indtægtskilde. På den anden side er der i dette konkrete tilfælde tale om en afvejning, idet den skriftlige fase kræver en begrænset indblanding fra underviserens side.

\section{Litteratur}

Boland, Richard \& Ramkrishnan V. Tenkasi. Perspective Making and Perspective Taking in Communities of Knowing. Organization Science 6(1995). 350-372.

Culnan, Mary J. \& M. Lynne Markus. "Information Technologies." Handbook of Organizational Communication. Eds. Jablin, Fredric et al. Newbury Park, London, New Delhi: Sage, 1987. 420-443.

Daft, Richard L. \& Robert H. Lengel. “Organizational information requirements, media richness and structural design”. Management Science 32(1986). 554-571.

Drotner, Kirsten et al. "Sproghandlinger og samtalestruktur." Medier og Kultur. Eds Drotner, Kirsten et al. Borgen, 1996. 120-135.

Gadamer, Hans-Georg. Wahrheit und Methode: Grundzüge einer philosophischen Hermeneutik. Thübingen: J.C.B. Mohr, 1960.

Habermas, Jürgen. "Hermeneutikkens krav på universel gyldighed." Hermeneutik - antologi om forståelse. Eds Gulddal, Jesper \& Martin Møller. Gyldendal, 1999. 206-237.

Huber, George P. \& Richard L. Daft. "The Information Environments of Organizations." Handbook of Organizational Communication. Eds Jablin, Fredric et al. Newbury Park, London, New Delhi: Sage, 1987. 130-164.

Hutchby, Ian. Conversation and Technology - from the telephone to the Internet. Cambridge: Polity, 2001.

Ong, Walter J. Orality and Literacy. London and New York: Routledge, 1982.

Salmon, Gilly. E-tivities - the key to active online learning. Routledge Falmer: 2002.

Short, John, Ederyn Williams, \& Bruce Christie. The Social Psychology of Telecommunications. London: John Wiley \& Sons, 1976.

Sproull, Lee \& Sara Kiesler. Connections - New ways of working in the networked organization. MIT Press, 1991.

Thompson, John B. "Medieret interaktion." Medierne og Moderniteten. En samfundsteori om medierne. København: Hans Reitzel, 2001 94-133.

Weick, Karl E. Sensemaking in Organizations. Thousand Oaks: Sage, 1995. 


\section{Appendiks A: Glance og Skype}

Figur 1. Skcrmdump (rekonstruktion) en 'deltager' i det virtuelle møde. Øverst ses en dialog-

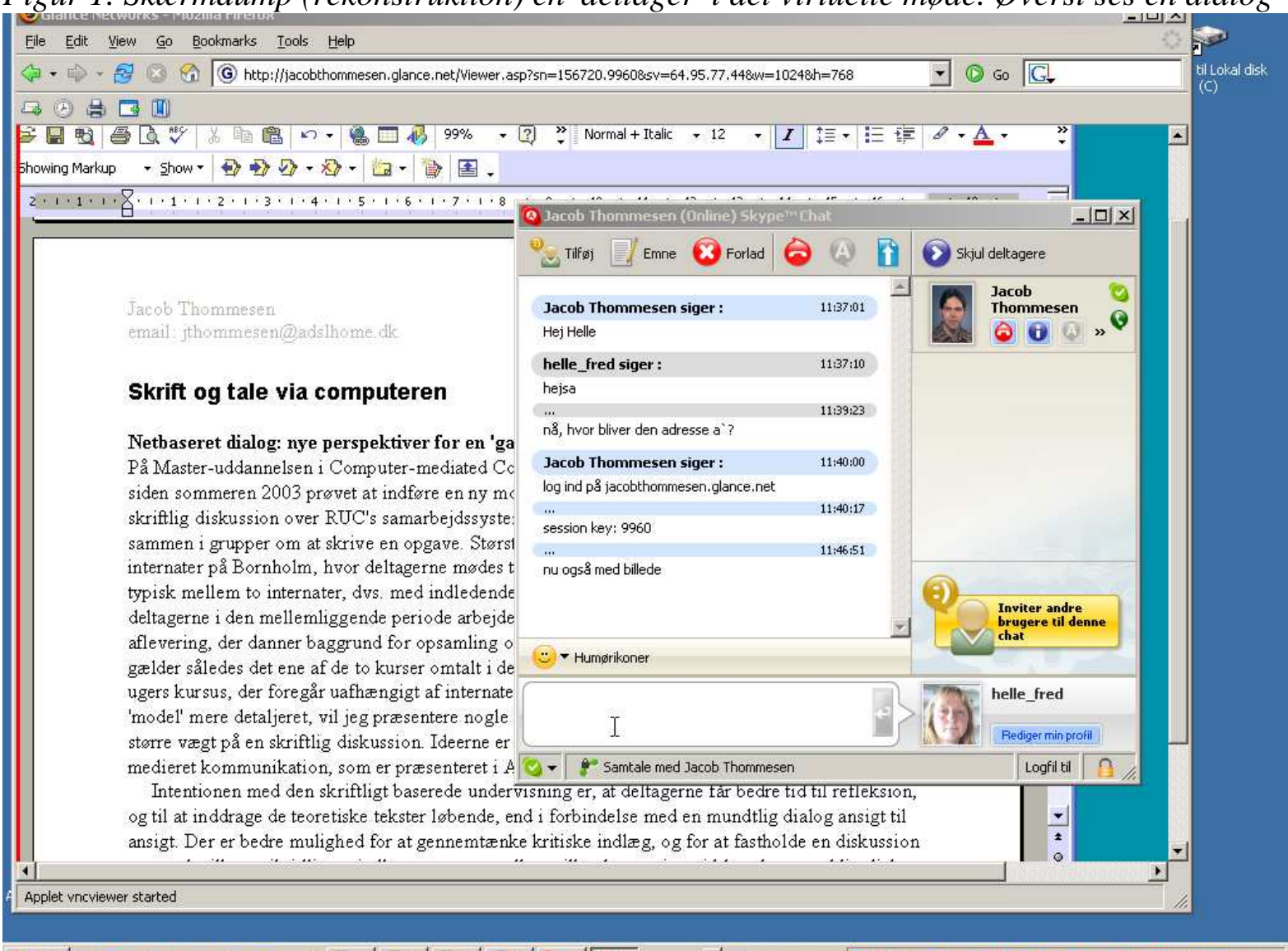

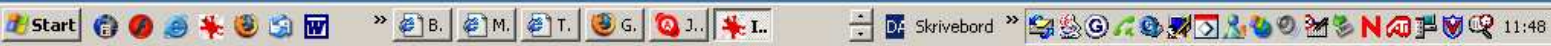
boks i Skype, hvor to mødedeltagere kan chatte med hinanden. I vinduet nedenunder kan deltageren se underviserens skcermbillede efter at have logget ind på en Glance-session.

\section{Skype: gratis internet-telefoni}

Skype er et program, der gør det muligt at føre en telefonsamtale via computeren over internettet. Ud over at downloade og installere programmet på computeren, skal man anskaffe og tilslutte et headset. Det er også muligt at bruge en mikrofon og almindelige højttalere, men det kan give problemer med interferens og dermed dårligere lydkvalitet (Jf. Jens Dørups artikel i dette temanummer). Derefter laver man en liste over kontaktpersoner, bestående af andre Skype-brugere.

Ligesom med bl.a. programmet Messenger kan man nu se, hvilke af ens kontaktpersoner der er online. Denne funktion giver i sig selv en form for 'awareness', og man kan således - i modsætning til den almindelige telefon - i princippet se, om folk er 'hjemme'. Hvis en kontaktperson er online, kan man ringe til vedkommende, indkalde til et telefonmøde bestående af max fem personer, eller sende en skriftlig meddelelse til en kontaktperson, hvorved man åbner en chat-funktion, dvs. kan føre en synkron skriftlig dialog. Ud over selve internetabonnementet er det gratis at ringe via Skype over Internettet - og mod betaling er det også muligt at ringe til almindelige telefonnumre. Se http://www.skype.com. 


\section{Glance: vil du se min smukke skærm?}

Glance er et program, der gør det muligt at lade andre se indholdet på ens computerskærm. Det kræver, at man tegner et abonnement på programmet (til ca. US \$50 om måneden). Når man skal bruge programmet, starter man en 'session' fra sin egen computer, hvorefter man indbyder deltagerne til at logge ind på en internet-adresse med et kodeord. Når de logger ind, åbnes et vindue, hvor de kan se indholdet af Glance-abonnentens skærm, dog uden at kunne interagere med den. På den måde kan Glance bruges til at vise f.eks. browsere, Word- eller Powerpoint-dokumenter eller grafik-filer. Se http://www.glance.net

\section{Appendiks B: Computer-medieret kommunikation - sam- menfatning}

Artiklen er baseret på en række antagelser om, hvordan computer-medieret kommunikation er påvirket af de teknologiske betingelser. Disse antagelser er baseret på en række undersøgelser og teorier om medier og CMC, som jeg vil præsentere her, idet jeg relaterer dem til en skelnen mellem to forskellige 'funktioner' i kommunikationsmedier: 1) intersubjektiv kanal, vs. 2) tegn med reference til et indhold.

\section{Media richness}

Teorien om 'media richness' inddeler på den ene side medier efter varierende grader af 'richness', og skelner på den anden side mellem to forskellige typer af meddelelser og opgaver (i organisationer), alt efter om de er præget af usikkerhed eller tvetydighed (Weick 1995). Teorien hævder, at rige medier er mest velegnede til opgaver/meddeleleser præget af tvetydighed, mens 'attige (på engelsk: lean) medier er mest velegnede til opgaver, der er præget af usikkerhed, men til gengæld éntydige. Et mediums richnes' defineres således som 'kapacitet til at forandre forståelse inden for et begrænset tidsrum’ og dets evne til at håndtere forskellige referencerammer eller perspektiver (Daft \& Lengel 1986; Huber \& Daft 1987).

At 'forandre forståelse' handler om at 'reducere tvetydighed'. Der er både en 'objektiv' og en subjektiv dimension i tvetydighed: på den ene side kan en meddelelse eller opgave i sig selv være kompleks og tvetydig, og på den anden kan det skyldes, at de involverede har forskellige forståelsesrammer eller 'forforståelser'. Derfor byder tvetydighed på andre udfordringer end usikkerhed. Usikkerhed kan reduceres ved at skaffe flere informationer, men for at reducere tvetydighed må deltagerne rette opmærksomheden mod de forskellige forståelsesrammer for at opnå en fælles tolkning og 'forandre forståelse'. Mens usikkerhed kræver flere informationer, kræver tvetydighed rige informationer med henblik på at 'afdække' bagvedliggende forståelsesrammer. At reducere tvetydighed svarer således til en hermeneutisk forståelsesproces (Gadamer 1960;Habermas 1999).

Da processen med at reducere tvetydighed kræver 'rige' informationer, kræver den også 'rige medier'. Et mediums 'richness' er baseret på fire forskellige dimensioner : 1) Kapacitet for hurtig feedback (interaktivitet); 2) Variation i nonverbale signaler ('cues'), f.eks. stemmeføring, ansigtsudtryk etc.; 3) Personalisering, dvs. grad af tilpasning til den individuelle modtager; 4) Sproglig variation, dvs. mulighed for at bruge et mindre formelt sprog. Groft sagt handler 'richness'-hierarkiet således om, i hvor høj grad mediet kan efterligne ansigt-til-ansigtsituationen. 


\section{Fortællinger og 'kognitive kort'}

Boland \& Tenkasi tager - om end på et andet teoretisk grundlag - udgangspunkt i den samme 'udfordring' som teorien om 'media richness', nemlig behovet for at kommunikere på tværs af forskellige faglige forståelsesrammer (Boland \& Tenkasi 1995). Men i stedet for at tale om 'rige medier' som et forsøg på at etablere et 'vindue' eller en kanal mellem kommunikationspartnerne, fokuserer forfatterne her på forskellige muligheder for at afdække eller udtrykke bagvedliggende forståelsesrammer. Dette kan således gøres ved at analysere de fortcllinger, hvormed deltagerne i en bestemt gruppe (f.eks. en faggruppe eller afdeling) beskriver deres erfaringer. Analysen kan afdække de bagvedliggende antagelser, der indgår i gruppens forståelsesramme. Eller det kan gøres ved at tegne 'kognitive kort', dvs. grafiske fremstillinger af årsagssammenhæng i en faggruppes perspektiv på et domæne. Forfatternes pointe er, at computermedier kan understøtte den gensidige forståelsesproces, hvis de udnyttes til at understøtte analyse af fortællinger eller fremstilling af kognitive kort. Og selv om den konkrete idé med 'kognitive kort' (endnu) ikke er blevet realiseret med succes, kan den dog generaliseres til et krav om at kunne udtrykke sig i andre former end sproget, f.eks. i form af grafiske illustrationer, billeder, eller i semiotiske termer: muligheden for at bruge ikke-lingvistiske tegn (som er noget andet end forskellige former for kropssprog, jf. ovennævnte spørgsmål om nonverbale 'cues'). Ønsket om at bruge fortællinger kan i øvrigt sammenlignes med en af de førnævnte dimensioner i 'media richness', nemlig 'sproglig variation': en formel sprogbrug vil nemlig udelukke brug af fortællinger.

Som allerede antydet giver disse to teorier anledning til at pege på et mere generelt spændingsforhold mellem to forskellige 'funktioner' i kommunikation: på den ene side skal et medium formidle interaktion mellem to eller flere parter, på den anden side skal mediet også have et 'indhold', dvs. referere til eller udtrykke 'noget'. Mediet skal både fungere som tegn og som (kommunikations-)'kanal' eller 'vindue'. Det betyder i øvrigt også, at man kan tale om et mediums 'richness' i to lidt forskellige betydninger: på den ene side kan mediet fungere som en 'bred' kanal ved at transmittere en masse 'cues' om kommunikationspartnerne (men det siger ikke noget om indholdet), på den anden side kan f.eks. grafiske illustrationer eller billedkunst fungere som 'rige medier' ved at transmittere 'rige data' om et bestemt indhold.

Telefonen kan her bruges til at illustrere forholdet mellem de to forskellige dimensioner/funktioner: på den ene side rangerer telefonen højt i 'richness'-hierarkiet, fordi den ved at transmittere fonetiske nonverbale cues (og høj grad af interaktivitet) fungerer som en rigere 'kanal' mellem kommunikationspartnerne end skriftlig kommunikation såsom e-mail og chat; på den anden side er den 'fattig' i tegn/reference-reference-funktionen ved at være bundet til sproget og ikke give mulighed for grafiske eller billedlige udtryk.

\section{Social presence}

Denne teori hævder, at kommunikationsmedier varierer i graden af 'socialt nærvær', afhængig af deres evne til overføre informationer om ansigtsudtryk, synsvinkel (i bogstavelig forstand), holdning, påklædning og stemmeføring (Short et al. 1976), svarende til en af de førnævnte dimensioner i 'media richness': 'nonverbale cues'. Graden af socialt nærvær påvirker den måde, deltagerne interagerer på: visse kommunikationsopgaver er meget afhængige af et sådant nærvær, men i andre situationer kan ansigt-til-ansigt interaktion i en arbejdsgruppe - med fuldt 'socialt nærvær' - dirigere for meget opmærksomhed mod selve kommunikationen og føre til ineffektive resultater. 
Selvom teorien altså umiddelbart fokuserer på 'kanal'-funktionen (indtryk af kommunikationspartneren) har den dermed også indirekte betydning for 'tegn'-funktionen. Der kan nemlig være en fordel ved 'fattige' medier (i betydningen 'færre nonverbale signaler om kommunikationspartneren), fordi de netop kan forstærke opmærksomheden på 'reference'- eller 'tegn'funktionen i mediet. Det svarer til 'media richness'-teoriens anbefaling af fattige (lean) medier til at håndtere opgaver, der handler om at reducere usikkerhed ved at indsamle (og behandle) informationer. Omvendt kan det også være en ulempe at fjerne opmærksomheden fra samtalepartnerne, når der er risiko for misforståelser i kommunikationen, der skyldes, at deltagerne har forskellige forudsætninger og referencerammer - tvetydige udsagn tolkes forskelligt, afhængigt af modtagernes forståelsesramme. Hvis indholdet er tvetydigt, eller hvis deltagerne har meget forskellige forudsætninger, kan der netop være behov for at dreje opmærksomheden væk fra 'indholdet' og over mod kommunikationspartnerens bagvedliggende forudsætninger.

\section{Reduced social/context cues}

Denne teori, der i høj grad er baseret på empiriske undersøgelser, synes umiddelbart i modsætning til richness-hierarkiet, idet den fremhæver en række positive aspekter ved computermediers bortfiltrering af nonverbale signaler om social kontekst (Sproull \& Kiesler 1991). Teorien bygger på en antagelse om, at ansigt-til-ansigt kommunikation (det 'rigeste' medium) er præget af nonverbale signaler om deltagernes sociale status, hvilket hæmmer den frie diskussion. På sådanne møder er der en meget ujævn fordeling af taletid, og deltagerne er mindre tilbøjelige til at kritisere uholdbare argumenter fra deltagere med højere status. Det er endnu mere problematisk, når f.eks. deltagernes status i et organisatorisk hierarki vejere tungere end status i form af faglig ekspertise. Ud over hensynet til status og hierarki er deltagerne i et ansigt-til-ansigt møde i det hele taget mindre tilbøjelige til at kritisere andres udsagn, da det opleves som en trussel mod den sociale tryghed - dette gælder især i (arbejds-) grupper, hvor den fælles identitet og sammenhængskraft spiller en afgørende rolle. Alt dette medfører, at beslutningsprocesserne er mindre effektive i rationel forstand.

I en computer-medieret, skriftlig kommunikation vil de sociale signaler være neddæmpet, og deltagerne er mere tilbøjelige til at gennemskue og kritisere tvivlsomme argumenter. Desuden er kommunikationen ikke tynget af begrænset taletid, og flere kan komme til orde. Det betyder, at diskussionen kan komme omkring flere alternativer og fokusere på selve argumentationen.

Med sin fokus på dysfunktionelle faktorer i direkte (ansigt-til-ansigt) social interaktion, og på positive konsekvenser af kommunikationsmediers 'sløring' af disse faktorer, har denne teori har således meget tilfælles med teorien om 'social presence', idet den dog fokuserer på spørgsmålet om hierarki og social status. Begge teorier peger på sociale processer, der kan hæmme (kvaliteten i) 'objekt-orienterede' processer såsom problemløsning. Umiddelbart synes disse teorier uforenelige med 'media richness'-hierarkiet, men i virkeligheden er der et vist overlap. Sproull \& Kiesler anbefaler også, at man mødes ansigt til ansigt i forbindelse med forhandlinger, hvor der er potentiale for konflikter (der jo også kan skyldes forskellige forståelsesrammer, og dermed kræver 'reduktion af tvetydighed'). Og når de generelt taler om at opnå bedre resultater og mere effektive løsninger, synes der især at være tale om opgaver, der kan kategoriseres som 'reduktion af usikkerhed'. 